University of St. Thomas, Minnesota

UST Research Online

2013

\title{
Toward an Integrated Vision of Undergraduate Liberal and Accounting Education in the Public Interest: the Holistic Development of Persons and Institutions
}

\author{
Brian P. Shapiro \\ University of St. Thomas, Minnesota, BPSHAPIRO@stthomas.edu \\ Michael J. Naughton \\ University of St. Thomas, Minnesota, mjnaughton@stthomas.edu
}

Follow this and additional works at: https://ir.stthomas.edu/ocbacctpub

Part of the Accounting Commons

This Paper is brought to you for free and open access by the Accounting at UST Research Online. It has been accepted for inclusion in Accounting Faculty Publications by an authorized administrator of UST Research Online. For more information, please contact asle4660@stthomas.edu. 


\title{
Toward an Integrated Vision of Undergraduate Liberal and Accounting Education in the Public Interest: The Holistic Development of Persons and Institutions
}

\author{
Brian P. Shapiro and Michael Naughton
}

\begin{abstract}
This paper puts forward a vision that integrates liberal and accounting education to engage students with the idea of vocation and pursuit of the common good through their chosen field of accounting. We adopt a common good definition of the public interest that seeks to advance not only the good of institutions and communities (mutual interests) but also the good of individuals (private interests). This approach engages students to critically reflect on how their life experiences, personal commitments, and future professional work can relate to one another. We first discuss disciplinary fragmentation in higher education and its implications for integrating liberal and accounting education. Next, we describe general learning objectives and concepts that support the integration of liberal learning and accounting education with a public interest orientation. We then apply the approach to critique accounting practices that arguably harm the public interest. The concluding section provides a summary and describes how accounting educators may adapt and scale an approach that fits their institutional setting.
\end{abstract}

Keywords: public interest; accounting education; liberal education; professional ethics; vocation.

\section{INTRODUCTION}

Accounting educators have recommended that more integration of liberal and accounting education will better develop accounting students' broad-mindedness, creativity, communication skills, and ethical awareness (e.g., Accounting Education Change Commission 1990 [hereafter,

Brian P. Shapiro is an Associate Professor and Michael Naughton is Director of the John A. Ryan Institute for Catholic Social Thought, both at University of St. Thomas.

We thank Dawn Massey, Joan Van Hise, John Koeplin, participants in the 15th Annual Symposium on Ethics Research in Accounting, accounting research workshop participants at the University of St. Thomas, and two reviewers for their comments and suggestions on earlier drafts.

Editor's note: Accepted by Robin W. Roberts. 
AECC 1990]; Cooper 1994; Cuganesan et al. 1997; Fogarty 2010; Langenderfer 1987, 302; Lister 2010; Massey and Van Hise 2009; Sundem 1999, Chap. 6, 1-3; Williams 1991; Zeff 1989, 204ff). More generally, Colby et al. (2011) advocated the integration of liberal education with all business education disciplines. But, disciplinary fragmentation in higher education typically exposes students to "mere assemblages of assorted disciplinary enterprises" (Maclntyre 2001, 2) and offers little guidance on how the business and liberal disciplines might fit together. In addition, corporate scandals at such firms as Enron and WorldCom, abusive tax shelter schemes promoted by prominent public accounting firms (e.g., Rostain 2006), and the more recent global financial crisis further reinforce the public's perception that ethics and liberal education remain insufficiently integrated with business and accounting curricula (cf. Swanson 2005). Moreover, the global financial crisis casts significant doubt on neoclassical economic assumptions about human incentives, the moral behavior of self-interested and socially detached individuals, and the ability of markets and enterprise risk management techniques to create well-ordered organizations and societies (e.g., Hopwood 2009, 798; McSweeney 2009, 839-840).

This paper argues that accounting education will better serve the public interest if it reduces disciplinary fragmentation among the liberal and business disciplines. Specifically, we put forward a vision that integrates liberal and accounting education in a manner that engages students with the idea of vocation and pursuit of the common good through their chosen field of accounting, and that engages their critical thinking about how their life experience, personal commitments, and professional practice mutually shape one another. We describe and critique what we believe generally is missing from an accounting education, and we provide illustrative examples that accounting educators can adapt and scale to fit their institutional setting.

We base our definition of the public interest on the concept of the common good, where the concern is to advance the good of institutions and communities (mutual interests) as well as the good of individual persons (private interests). Our common good approach to the public interest has several important implications. First, it encompasses more than an aggregation of the net private economic utilities of different stakeholders. Rather, it also recognizes that the good of individuals encompasses not only economic but also psychological, emotional, cultural, and spiritual wellbeing, and that some of these goods may be held in common by all. Second, the common-good approach to the public interest complements code- and rule-based approaches to professional accounting ethics by engaging students to see accounting and business problems within a larger social and cultural context than they typically are accustomed to seeing. Third, while private and mutual interests may coincide under ideal circumstances in a well-functioning society (cf. Douglass 1980, 105; Lewis 2006, 698), in reality conflicts will sometimes arise between personal commitments and codified professional codes of conduct (cf. Martin 2000, 49), and between the welfare of individuals and of society (cf. Douglass 1980; Martin 2000, 6-7, 46; Williams 1981, Chap. 5). Consequently, it also is important to engage students to reflect realistically on the tensions and conflicts that may arise between their private interests and the professional demands of their future work.

We also recognize that structural factors in higher education encourage disciplinary fragmentation and discourage the kinds of integration we advocate. For example, Blanthorne et al. (2007) and Hurtt and Thomas (2008) concluded that it will be difficult to integrate liberal and accounting education as long as state and professional bodies continue to emphasize the AICPA's Code of Ethics and other rule-based approaches to practical problems, or if accounting educators prefer to emphasize professional codes and ignore (for example) philosophical or psychological theories of virtue ethics and character development when they address practice-oriented ethical problems. Other obstacles are cultural and reflect more general trends and attitudes, including a 
careerist orientation that tends to suppress the possibility of work as a vocation or socially meaningful activity, an emphasis on shareholder wealth and profit maximization to the exclusion of other vital and legitimate social purposes of business, and a general preference for efficient technique and instrumental rationality in business decision making.

When we apply our approach to illustrative examples we are mindful of structural barriers to integration. We first describe in more detail the structural tendencies toward disciplinary fragmentation in higher education, and then consider their implications for developing more holistic approaches to people, the purpose of business, and the public interest. Next, to explore how the liberal arts and humanities can be better integrated with business and accounting, we apply concepts from philosophy, theology, and literature to the contrastive themes of career and vocation, work and leisure, and the economic and socio-cultural purposes of business. We develop and use many of our examples in a liberal arts course that satisfies a general requirement at our Catholic university. The course deliberately and intentionally engages students to explore the intersection between the humanities and business disciplines. We recognize that many institutions of higher learning differ from ours, and that the question is likely to arise as to how elements of our approach can be generalized and scaled to fit traditional accounting courses at other types of colleges and universities. Our point is not that all accounting educators should apply the same set of philosophical, theological, or literary examples in their courses, nor that they should necessarily apply their examples as extensively as we do. Rather, by describing general learning objectives and then by applying them to a range of specific examples, we aim to illustrate how other accounting educators could develop, scale, and apply their own examples in an existing accounting curriculum in a variety of colleges and universities, whether secular or faith-based, and whether teaching-focused or research-focused.

The remainder of this paper is organized in four sections. The first section discusses disciplinary fragmentation in higher education and its implications for integrating liberal and accounting education. The second section describes the general learning objectives and concepts that we argue can support the integration of liberal learning and accounting education in the public interest. The third section applies the integrative approach to some specific examples of accounting institutions and practices that arguably harm the public interest. The concluding section provides a summary and describes how accounting educators may adapt and scale an integrative approach to fit their institutional setting.

\section{DISCIPLINARY FRAGMENTATION IN HIGHER EDUCATION AND ITS IMPLICATIONS FOR ACCOUNTING EDUCATION IN THE PUBLIC INTEREST}

Boyer's (1990, 1992) discovery, application, and integration dimensions of scholarship relate to the goal of integrating liberal and accounting education. The discovery dimension recognizes that liberal education cultivates the capacity of students to understand themselves as free and intelligent persons who seek to know the true, do the good, and experience and create the beautiful. The application dimension in professional degree programs such as business or accounting recognizes that courses also must convey the hard and soft skills that students need to succeed professionally. The integration dimension requires deliberate and intentional linkages between theory and practice, for example by integrating concepts from philosophy or literature with professional knowledge. More recently, Colby et al. (2011, ix) similarly proposed that a liberally education person should be able to engage in analytic reasoning, multiple framing of complex 
decisions and judgments, and "finding and making connections of personal meaning between what one does and who one intends to become" (emphasis added).

A deliberate integration of theory and practice can engage accounting educators and students to theorize about the personal and professional dimensions of a whole person (cf. McPhail 1999; Martin 2000). The goal is to connect liberal and professional knowledge in a manner that equips students to make decisions that are both technically and morally sound (cf. Maclntyre 2001, 2). Various theological, philosophical, and narrative traditions around the globe envision people in relation to their communities, other species, and the natural environment (cf. Maclntyre 1984, Chap. 14; Gallhofer and Chew 2000; Gallhofer et al. 2000). In these traditions, the development of whole persons encompasses not only physical, material, and economic wellbeing, but also psychological, emotional, cultural, and spiritual wellbeing. At least some of these dimensions of human flourishing can be fully achieved only through participation in a community, organization, or other institution. To the extent that these dimensions are both shaped and experienced by others, they are goods held in common. A holistic approach to persons, thus, can be extended to evaluate institutions in terms of their positive or negative impact on human flourishing.

Integration between liberal education and business can occur in both directions, whereby the business disciplines are shaped by ideas from the liberal disciplines, and the liberal disciplines are professionalized and framed in terms of practical problems (Colby et al. 2011, xi). Few curricular programs in the United States, however, currently make either type of integration explicit (Colby et al. 2011, 51; MacIntyre 2001, 6). Instead, disciplinary fragmentation in higher education is the more typical norm and can be traced to several practices.

Specifically, higher education has been institutionalized to emphasize disciplinary differentiation and specialization, such that the different disciplines have become increasingly fragmented and seen as largely unrelated subject matters. For example, interdisciplinary research in academia is discouraged by government bodies and universities whose journal ranking and research funding systems privilege publication in highly specialized, single-discipline journals (Parker 2012, 60). In addition, general undergraduate education requirements are typically seen as "something to be got through in order to advance beyond it into the specialized disciplines" (Maclntyre 2001, 5-6). This view is further reinforced when corporate job recruiters look to hire candidates for skills that will benefit the company in the short run (Colby et al. 2011, 52). These conditions have not changed much since Cornell University President, Frank Rhodes, observed that "Rarely have [higher education institutions] attempted to integrate liberal and professional education in ways that have meaning for all students; rarely have they been able to link high standards of scholarship and professional practice to critical thinking on the fundamental issues of life" (quoted in Stark and Lowther $[1988,5])$. In sum, these trends discourage interdisciplinary awareness, obscure the relevance of liberal learning for one's personal and professional undertakings, and reinforce a skeptical belief that it is not possible to improve our understanding of how the disciplines relate to each other (cf. Maclntyre 2001, 5).

In the accounting, finance, and economic disciplines, the relations between business and liberal learning, and the relations between personal commitments and professional ethics, are further obscured by the prevailing classical liberal view of people as individuals who aspire to maximize their freedom in part by estranging themselves from the constraints of social relationships and inherited traditions:

The drive to facilitate private choice produces social atomism because the ability to expand the realm of private choices depends on disentangling oneself from the networks of social obligations that might impinge on one's ability to choose freely. Family, tradition, 
community, or religious duties, are all manifestations of dependencies that must be cast off to expand the realm of individual choice. (Smith 2008, 33)

But, while inherited cultures and institutions impose accountability expectations and constraints that are not entirely of our own making, and thereby impose some constraints on our freedom to choose, they also define our social identities and accountability relationships with other people:

I am brother, cousin and grandson, member of this household, that village, this tribe. These are not characteristics that belong to human beings accidentally, to be stripped away in order to discover 'the real me.' They are part of my substance, defining partially at least and sometimes wholly my obligations and my duties. Individuals inherit a particular space within an interlocking set of social relationships; lacking that space, they are nobody, or at best a stranger or an outcast. (Maclntyre 1984, 33-34)

Accounting researchers have similarly documented that people who see and understand themselves as social beings in specific and recognizable accountability relationships are more likely to behave in accordance with applicable norms (cf. ljiri 1975, ix), act on behalf of others (cf. Shearer 2002), give adequate reasons when asked to explain their conduct (cf. Roberts and Scapens 1985, 447), and see how their actions make a meaningful difference to the welfare of their communities (Jacobs and Walker 2004, 377; Roberts 1991, 356). An implication is that individuals whose personal commitments and values are rooted in a healthy social community will be better positioned to advance the public interest.

Nonetheless, a still prevalent view of professional ethics maintains that professionals should set aside their personal values, feelings, and interests in order to best meet their professional responsibilities (Martin 2000,3). This view manifests itself as a tendency to reduce professional ethics to duties and dilemmas, where professionals apply standardized codes to ambiguous or conflict-ridden situations, and where the professionals' personal moral commitments are not to play a meaningful role in guiding their work (Martin 2000, 5). Code- and rule-based approaches to teaching accounting ethics are essential for educating responsible future accountants, but if that is all that we teach, then by default we leave the task of integrating one's personal commitments and professional responsibilities up to the individual.

\section{Public Interest Implications of Disciplinary Fragmentation}

The International Federation of Accountants $(2010,4)$ proposed a public interest requirement that any public policy, action, process or condition exhibit "Respect for cultural and ethical diversity." While the details of this proposal have yet to be worked out in specific applications, it seems reasonable to expect that respect for cultural diversity in higher education should include steps to encourage students to work from within the particularities of their own tradition, but also engage in a meaningful dialogue with people from other traditions (cf. Marsden 1997, 10). A meaningful dialogue in a pluralistic community must be accessible to people of different political, ideological, cultural, or spiritual beliefs (cf. Marsden 1997, 45), and the participants in the dialogue must also be receptive to learn from other people's traditions. Moreover, treating others with dignity and respect will rule out proselytizing and coercive behavior. Some might argue that we should avoid conflict simply by removing culturally specific references from all discussions of professional ethics. But an accounting curriculum that suppresses students' cultural traditions and the personal values they may have inherited from their families, schools, and other institutions would lose sight of an important basis for 
moral sensibility and ethical reasoning, and ultimately could harm students' ability to understand and develop their future professional work in relation to the public interest.

Indeed, failure to integrate liberal education with business can prevent business professionals from advancing socially just practices. To illustrate, Alford and Naughton (2001, Chap. 1) described two prototypical personalities-secularizers and spiritualizers-who fail to effectively integrate their faith or spiritual orientation with the practicalities and social-justice demands of work (Alford and Naughton 2001, Chap. 1). The point of discussing these two types of personalities is not to classify people into simple categories but, rather, to bring to light and examine some problematic and often implicit orientations that people may bring to their work. Secularizers argue that religious or other beliefs about social justice (or other public interest issues) can have private meaning for individuals, but should have nothing to do with one's work in a corporation (cf. Carter 1999, Chap. 10; Martin 2000, 3-5). Spiritualizers seek an engagement of faith with work from a distorted evangelism or misguided enthusiasm that threatens the freedom of others, and they typically ignore the practical and structural details necessary to sustain a good business. That is, despite their faith orientation and deeply held convictions, spiritualizers tend not to use their spiritual beliefs to critically examine whether an organization's policies and procedures are fair, socially just, or enable people to develop both themselves and others through their work (cf. Nash 1994, Chap. 2). Or, they perform a good critique but when they offer recommendations about how to remedy social injustices they fail to adequately consider the practical implications of bringing about social reform in a resource-constrained and imperfect world (cf. Yuengert forthcoming).

\section{Implications for Integrating Liberal and Accounting Education}

Disciplinary fragmentation has implications for how to go about integrating liberal and accounting education. Colby et al. (2011) argue that integration of liberal and business education requires a combination of intentional institutional support (Colby et al. 2011, 69), individual instructors' pedagogical choices, and a deliberately structured program of courses and experiences (Colby et al. 2011, 112). A course or program of courses is deliberately integrative if it is consciously planned, organized, and delivered in a manner that explicitly engages students to see connections between foundational ideas from the humanities and the practical and social concerns of business and accounting (cf. John Paul II 1990; Newman 1982). The conditions that can support integration will, of course, vary across institutions of higher learning. Colby et al. (2011) accordingly acknowledged that what works best will largely be a function of institutional fit (Colby et al. 2011, 113), and moreover that what works well in one institution cannot simply be applied to another institution without some translation and adaptation (Colby et al. 2011, 131).

Our university exhibits some of the above conditions for disciplinary integration. Specifically, undergraduate business students at our university take a course in business ethics early in their business degree program, and also must satisfy extensive general requirements that include two philosophy and three theology courses. The first philosophy course focuses on the nature of the human person and the second course focuses on ethics. The first theology course provides an introduction to Christian theology. The second course offers choices in different theological fields, scripture, history, and systematic and moral theology. All third-level theology courses build upon the skills, knowledge, and methodologies acquired in the prior theology and philosophy courses, and they engage Catholic or other faith traditions' relation to culture. Of the many third theology course offerings, some focus on the relation between faith and one's chosen professional field. Our course is a senior capstone experience that satisfies the third theology course requirement and specifically applies theological and philosophical perspectives to the management professions. 
More specifically, the course explores the organizational, technological, and cultural forces that managers, accountants, and organizations encounter daily, and addresses such questions as "What is a good accountant and how does he/she contribute to the common good?" Finally, a financial grant enables us to team-teach our course, with each author receiving credit for teaching a full semester course.

We recognize that most accounting educators will have fewer and different resources at their disposal to integrate liberal and accounting education, and that in most colleges and universities the integration must occur within a currently existing traditional program of accounting courses. Our objective is not to persuade others to replicate all elements of our approach, but rather to describe some general principles and offer some illustrative examples so that others may scale and adapt our approach to fit their own institutional settings. We believe that even just a partial application of our approach can bring incremental public interest value to an accounting education.

\section{INTEGRATING LIBERAL AND ACCOUNTING EDUCATION: ADVANCING THE PUBLIC INTEREST THROUGH HOLISTIC DEVELOPMENT OF PERSONS AND INSTITUTIONS}

Our vision of an accounting education in the public interest applies an interdisciplinary engagement of philosophical, theological, and other perspectives from the humanities to engage students to explore the relation between their personal and future professional lives, reflect on their future accounting work as a vocation, and consider a wider set of social purposes for business than is commonly examined in most undergraduate business programs. The approach described below reflects a commitment to the idea that students' self-knowledge, in addition to their technical knowledge and practical skills, can beneficially guide how they analyze the public interest implications of situations they may encounter in their accounting work (cf. McPhail 1999, 843). The structure of this section reflects our common good approach to the public interest, where the good of individuals and the good of institutions and society both matter. We first describe the holistic development of individual persons, the idea of vocation as meaningful work, and their relation to the public interest. We then adopt an institutional focus and consider the public interest implications of alternative views on the purpose of business. An interdisciplinary approach to these themes can be achieved through different combinations of course readings, films, written assignments, and oral discussions that guide students to integrate and contrast specific ideas about work, leisure, vocation, the purpose of business, and their chosen field of accounting. Our specific examples illustrate only some of the possibilities.

\section{Seeing Whole Persons in Relation to the Public Interest: Seeking Wider Unities}

A holistic approach to accounting education engages students to see more connections between the personal and professional dimensions of their lives, to reflect more deeply on the kind of person they aspire to become when performing the role of accountant or manager, and to imagine the contributions they can make for the benefit of society. The concept of a whole person is related to the concept of integrity, which means "unity, interrelatedness, integration, and harmony among aspects of character" (Martin 2000, 203). However, complete unity among all major aspects of a person's life is never fully attainable. Rather, as Martin $(2000,203)$ observed, "Virtues can be manifested in varying degrees and in some contexts but not others... there can be genuine subunities and limited integrity within particular domains of life, without unity overall... [But] integrity provokes us to seek wider unities" (emphasis added). This belief that it is possible to 
achieve greater personal integrity bears some similarities to Rorty's (1989, Chap. 2) belief in the socio-historical contingency and malleability of selfhood, but it also embraces Wilson's (1993, Chap. 1) argument that having a moral sense is an inherent feature of the human condition. Compartmentalization of the different parts of our lives, and the morally questionable roles it can lead us to play, may not be entirely avoidable (cf. Colby et al. 2011, 81-82). But this does not disprove the possibility of a core moral self and it need not discourage us from seeking wider unities. Still, while our attempts to discover wider unities can help us to see more connections, it also can make us more acutely aware of irresolvable conflicts that may arise between our private interests and our professional responsibilities.

\section{Integration between Work and Spirituality}

The integration of work and spirituality can bridge one's personal interests and the public dimensions of a professional career. We have found, however, that our undergraduate students generally find it easier to see how work relates to their instrumental goals (e.g., they may be concerned to pay down their student debt) than how work relates to spirituality. Accordingly, we draw from multiple readings to expose students to different perspectives on the work/spirituality relation. In one example, we use the two creation stories in the Book of Genesis from the Hebrew Scriptures to explore the relations between work, leisure, spirituality, and reflection. The two creation stories describe two types of persons, both of who exhibit tendencies that exist within us in varying degrees and whose estrangement from each other makes it difficult to integrate our spirituality commitments with the practical and social-justice demands of our work (see the earlier discussion of spiritualizers and secularizers). The Adam and Eve characters in Genesis Chapter 1 (hereafter, Adam 1) focus on practical work as a way to improve their own and others' lives and, thus, are concerned to contribute to the welfare of their communities, but they have little interest in religion or spirituality. Adam 1's dominance in the corporate world is manifested by an emphasis on instrumental or practical reason. In contrast, the Adam and Eve characters in Genesis Chapter 2 (hereafter, Adam 2) have a more spiritual and philosophical outlook that enables them to experience a deep solidarity with others, but they cannot completely translate their spiritual experience into the pragmatic categories of Adam 1 (Soloveitchik 1965, 95; Shapiro 2009, 949).

Most undergraduate accounting programs arguably tend to emphasize Adam 1's instrumentality and suppress or ignore Adam 2's spirituality. While an irresolvable tension exists between Adam 1 and Adam 2, the question arises as to how might we better integrate these two types within us to more effectively advance the public interest. An integration of Adam 1 and Adam 2 can advance the public interest, as follows. Adam 2's spirituality and solidarity with others motivates his public service orientation, but he cannot act effectively without Adam 1's practical knowledge and skills. Similarly, Adam 1 needs Adam 2's self-reflective capacities and solidarity concerns to guide his application of science and technology to enhance, rather than diminish, other people's lives.

Students can be engaged to further explore these issues through open-ended questions such as: (1) How might a meaningful dialogue between Adam 1 and Adam 2 mitigate spiritualizing and secularizing tendencies? (2) What is your concept of a successful businessperson? and (3) Which of the two Adams do you believe better approximates that successful businessperson? The point of this line of questioning is to engage students to think more deeply about the relations among the practical dimensions of their work, spirituality, and the public interest. Students who might otherwise be unreceptive to a biblical approach to these ideas might be interested in The New York Times column in which David Brooks (2012) applied Soloveitchik's analysis of Adam 1 and Adam 2 to the Jeremy Lin N.B.A. phenomenon. 
A second example involves Pieper's (1948) philosophical analysis of the relation between work and spirituality. Pieper's analysis is similar to critical theory's analysis of work and human emancipation. For example, he critically evaluated the modern tendency to instrumentalize and reduce everything to work, and the tendency of many people (including professionals) to become proletarianized (i.e., bound to the world of work). As Pieper $(1948,43)$ described it, a workaholic's life is "fully satisfied by the working-process itself because [the moral-spiritual] space has been shrunken from within, and because meaningful action that is not work is no longer possible or even imaginable." In some respects, the estrangement from moral-spiritual concerns may seem desirable because it promises to free us from conflicts among our personal and professional commitments. To some, the loss of a moral-spiritual center may not seem at all disturbing. But Williams $(1981,80)$ more recently argued in his critique of Utopian enlightenment that it is not possible to radically transcend value incoherencies without loss:

You might perhaps bring about a society whose values were less conflicting, more clearly articulated, more efficient, and people, once arrived in this state might have no sense of loss. But that would not mean there was no loss. It would mean that there was another loss, the loss of the sense of loss.

Pieper (1948, Chap. IV) proposed that we can overcome our workaholic tendencies by participating in what he calls "leisure"-a contemplative, reflective, and receptive attitude of the mind, such as may be experienced in the cessation of work on the Sabbath (cf. Heschel 1951). Other spiritual traditions around the globe similarly recognize the benefits of prayer, contemplation, reflection, or meditation. Students who come from different cultural backgrounds can be encouraged to draw from their own traditions to see themselves not only as actors and achievers, but also as reflective, contemplative, and receptive individuals whose personal and professional needs have psychological, emotional, cultural, and spiritual dimensions. Greater awareness of these dimensions paves the way for a receptive attitude toward alternative perspectives on the meaning and social significance of work.

\section{Career versus Calling}

Different attitudes toward work have implications for seeing wider unities among one's personal and public commitments. When work is seen primarily as a career, the tendency is to focus instrumentally on one's own personal achievements, social status, and extrinsic rewards. An instrumental view of work can make it difficult to see the relationship between personal and societal interests, or distinguish between satisfying a client's (and one's own) interests and the legitimate interests and needs of the broader society. In contrast, a vocational view of work is consciously directed toward advancing "the welfare of the world in a larger sense" (Colby et al. 2011, 129). Meaningful accounting work not only encompasses the craft objectives of excellent technique and efficiency, but also makes a positive contribution to organizations, societies, and the people who participate in them.

While we prefer to use the words "calling" and "vocation" to denote work that is both personally and socially meaningful, others might prefer instead to use words like "professional caring" (Martin 2000, Chap. 5) or "ground projects" (Williams 1981, 12). The specific labels are less important than the underlying concept of pursuing a line of work that not only utilizes one's talents and interests, but also contributes to the wellbeing of communities (cf. Martin 2000, 29). Martin $(2000,73)$ summarized the implications for professional ethics as follows:

Whether we call it. . professional caring, or vocation, or Williams' (1981) ground projects, the common theme is that work is related to a larger good, and this relation gives one's 
life meaning. It also guides our work so that other concerns, such as the desire for more money, don't lead us to cut corners that would harm others.

Two dimensions of vocation in particular are especially prominent in Western theological traditions. The first dimension calls upon us to use our gifts, talents, and interests to meet society's needs and advance the common good (Hardy 1990, Chap. 3). This invites us to engage accounting students to reflect on their talents, abilities, and interests; on how they will bring them to bear on their future work as accountants; and on how their work in a particular institutional setting might advance or harm the public interest. Some accounting students describe themselves as being "good at numbers" or being "a numbers person," without much further elaboration. These students need to be engaged to reflect more on how they might apply these and other skills, interests, and abilities to achieve socially beneficial ends.

A second dimension of vocation inspires us to become a certain kind of moral person regardless of the specific station, role, or occupation we might occupy. This moral theme applies to all professions. In the accounting profession, people who are "good at numbers" are not simply neutral technicians. An investment planner can, for example, use her skills to help her clients plan better for their families' financial security. Quantitative skills also can be employed to mobilize awareness of what is important. As the Union of American Hebrew Congregations $(2001,28)$ put it, "Counting is a metaphor for paying attention. It is not about the number, but about the awareness that paying close attention generates."

Accounting educators who teach in undergraduate business programs must deal with the reality that most students lack significant direct experience with the kind of accounting work they will perform after they graduate. Lack of significant work experience can limit students' ability to imagine what the intersection of their personal and professional commitments might be like. We can, however, engage these students to begin to reflect on the personal meaning and public interest potential of their future work by asking them to examine the social roles they have occupied so far in their lives (e.g., as son or daughter; brother or sister; mother or father; citizen; and so on), the rights and obligations that come with those roles, and the special gifts and talents they exercise when they perform the roles. In addition, we can guide students to explore how these themes relate to the purpose of business and apply to specific accounting problems, as discussed next.

\section{Institutional Focus: Alternative Perspectives on the Purpose of Business}

Most undergraduate business students learn from their introductory finance or economics courses that the purpose of business is to maximize profit and shareholder wealth (e.g., as articulated by Friedman [1970]). Students at our university have reported that they receive exam questions about this very topic and in order to earn credit they must give the profit-maximization answer. This one-sided framing is consistent with the dominant shareholder primacy emphasis in introductory accounting textbooks (e.g., Ferguson et al. 2005), and is reinforced in both academia and practice by neoliberal economic beliefs about how self-interest, profit maximization, and markets can most efficiently create socially beneficial order (Baker 2005). We have found that students who have been exposed to these beliefs generally are more receptive to explore alternative perspectives on the social purpose of business when we introduce and apply them to an actual company, before we more critically contrast the alternatives with the shareholder/wealth maximization view.

\section{Alternative Perspectives on the Purpose of Business}

An intentional and deliberate approach to introducing alternative perspectives on the purpose of business can be achieved by reminding students of the liberal learning objective of multiple 
framing - the ability to work with different and sometimes incompatible analytic perspectives, and to develop awareness of how different perspectives frame experience differently (Colby et al. 2011,60 ). For instance, multiple framing can be used to explain that while profit is necessary to sustain a for-profit organization, other purposes of business besides profit maximization can be intellectually and analytically entertained.

Our common good definition of the public interest suggests three competing dimensions of business, each of which must receive some attention in a healthy organization. The three dimensions each can be framed in the first person plural: (1) Identity - who are we as an organization and how do we advance the development and quality of life of our employees? (2) Mission - who do we serve and what products and services do we provide? and (3) Stewardshiphow do we sustain and grow our resources? Specht and Broholm (2009) describe these three dimensions in their Three-Fold Model of Organizational Life, with questions to prompt an organization's leaders to think more deeply about how the three dimensions apply to specific problems and dilemmas they have encountered. The three-dimensional approach can be applied to any organization, whether profit or not-for-profit. Most accounting students probably have given more thought to the Stewardship dimension and its role in sustaining and growing organizations, but a broader public interest orientation also should address the Mission and Identity dimensions.

The three-fold approach provides a simple conceptual tool for exploring the tensions and conflicts that can arise when organizational participants focus mainly on one dimension to the detriment of the others. For example, an almost exclusive Stewardship focus on profit maximization (e.g., through expense reduction activities or competition for the organization's limited resources) can harm both Identity (e.g., through layoffs and reductions in employee benefits, health, and safety) and Mission (e.g., through reduced product quality and safety). A healthy organization that is committed to serve the public interest might frame its Stewardship dimension something like "How do we sustain and grow our resources so that we may grow stronger as an institution and be better able to achieve our Mission and Identity objectives?" This is broader in scope than the question "How do we sustain and grow our resources so that we can maximize shareholder wealth?" Likewise, a heavy emphasis on the Identity dimension might create an atmosphere of employee entitlement that could significantly harm an organization's Stewardship and Mission. Identity objectives must be pursued in a sustainable manner (Stewardship) that also does not harm the entity's ability to serve its customers (Mission).

The three-fold approach can be applied to case studies of actual organizations that attempt to reasonably address all three dimensions. For example, Timberland Company's CEO, Jeffrey Swartz, framed the purpose of his business in terms of the relation between commerce and justice (Austin et al. 2004). The Timberland case has the advantage of engaging the purpose of business concept not as an abstract question, but with a real company with a real history and with real people. Swartz was interviewed on The Colbert Report, with Colbert playing the role of Milton Friedman (1970) arguing that the purpose of a business should only be to maximize shareholder wealth. ${ }^{1}$ The humorous exchange between Colbert and Swartz reveals how Timberland Co. engaged with community involvement, environmental stewardship, and responsible global labor practices while still earning a sustainable profit.

A case study such as the above provides some background to more formally compare and contrast alternative models of business organizations and the kinds of communities they cultivate. We describe the alternatives as the shareholder, stakeholder, and common good models. Each model has normative dimensions, as each conveys a different view of the kind of community an

\footnotetext{
${ }^{1}$ See http://www.colbertnation.com/the-colbert-report-videos/78244/november-14-2006/jeff-swartz
} 
organization should cultivate. All three models recognize that profit or other resource acquisition methods are essential for long-run organizational sustainability, but the stakeholder and common good models also give more weight to the Identity and Mission dimensions. Thus, we believe that the stakeholder and common good models are better able to advance a public interest concern with the development persons and institutions.

More specifically, the shareholder model views the corporation as a "society of shares" and privileges the shareholder as the central player on the corporate stage. As in Friedman's (1970) view, the executives who manage shareholder assets are seen as not having the power or responsibility to choose among values, and instead are seen as passive agents who only seek (and should only seek) to manage the company's resources for the benefit of the shareholders. Consequently, other stakeholders have little voice in the conduct of a company's affairs.

In contrast, stakeholder models recognize the claims of other parties besides shareholders, including employees, customers, suppliers, and so on. But while stakeholder models can raise awareness of the needs and demands of different stakeholder groups, they cannot resolve conflicting and competing stakeholder demands. Moreover, like the shareholder model, the stakeholder model tends to view relationships in terms of contracts, instrumental exchanges, and economic benefits. For example, the International Federation of Accountants (2011) recommended that the net public interest impact of accounting actions, decisions, and policies should be assessed by aggregating their impact on the private economic interests of individuals and groups who participate in a marketplace for goods and services. This approach largely ignores the other dimensions that contribute to human flourishing, and it does not provide a language for describing goods held in common by all.

Finally, the common good model includes, but is not limited to, honoring contracts and engaging in instrumental exchanges, and it encompasses more than just the aggregation of individual private interests (cf. Douglass 1980, 107). It recognizes the legitimate needs of different stakeholders, but also views the corporation as a community of persons whose goal is to establish meaningful social relationships. Gilligan's (1982) ethics-of-care approach to professional ethics similarly raises awareness of the multiplicity and importance of human relationships, but like the stakeholder models it does not offer an easy algorithm for adjudicating conflicts. Martin $(2000,213)$ summarized the challenge to reconcile conflict as follows:

Gilligan's approach of moral reasoning envisions integrity as the search to maintain all moral relationships relevant to particular contexts. What is needed is not absolute ranking of principles, but skill in reconciling competing legitimate demands.

Although none of the three models provides an algorithm that can completely reconcile or resolve conflicting interests, the common good model engages students to seek wider unities and solidarities among a more diverse set of stakeholders, and it engages them to think about a richer set of foundational concepts that bear on the public interest. Nevertheless, regardless of the model students might prefer, our principal objectives are to augment their ability to work intellectually with each of the analytic perspectives and to engage them to reflect on how each perspective frames the purpose of business.

\section{FURTHER APPLICATIONS TO ACCOUNTING PRACTICES AND INSTITUTIONS}

Below we illustrate how public interest concepts can be applied to problematic accounting institutions and practices. Some of the issues we raise have been discussed and analyzed by others, 
most recently by Arnold (2009), Hopwood (2009), McSweeney (2009), Power (2009), and Williams (2010). We extend those analyses by introducing foundational concepts from the liberal arts and humanities, and by exploring their implications for an accounting education in the public interest.

\section{Critique of Financial Accounting and Reporting}

The first example develops the shareholder primacy bias and its implications for other stakeholders. We begin with the observation that the balance sheet equation defines an entity's resources as originating from investors and creditors (i.e., Assets = Liabilities + Equities). As others have observed, the balance sheet equation and the prevailing financial accounting reporting model's emphasis on capital providers attributes most value creation to capital, even though employees and other stakeholders also contribute to an organization's success. The general liberal learning objective is to raise students' awareness that when they occupy a particular role as accountant they will be expected to be loyal to particular values and relationships, and that a commitment to advancing the public interest also will require them to engage with other potentially conflicting relationships and values (cf. Colby et al. 2011, 52).

One approach to raise students' awareness of the legitimate rights and needs of a more diverse group of stakeholders is to engage them to reflect on the diverse origins of an organization's resources. For example, organizations inherit the diverse contributions of past generations of people, their surrounding community's social mores and physical infrastructure, and natural resources they did not themselves create. Spiritual traditions around the globe emphasize the inherited nature of most private and public resources. Those traditions also emphasize the duties and obligations that the inherited resources impose on each member of a community. The common good approach to the public interest recognizes that some goods are (or should be) held in common by all and be preserved or maintained for the benefit of all.

A second example builds on the widely recognized problem of externalities and their implications for calculating and reporting a company's income and financial position under current generally accepted accounting principles. For instance, the systematic underreporting of certain externalities (e.g., natural resource degradation or depletion) can make a socially unjust distribution of resources to shareholders and managers seem legitimate, even though it fosters an incomplete understanding of the organization's negative impact on other people, other organizations, and the natural environment. The omission of significant costs overstates the reporting entity's wealth creation during a period, understates its negative impact on the natural environment and surrounding community, and thereby overstates the entity's net resources available for distribution to shareholders. In addition, the externalities problem sheds moral light on how accounting calculations manufacture profits and enable certain stakeholders to extract it for themselves (cf. Hopwood 2009, 798). Finally, the omission of positive externalities also can mask an organization's contributions to the common good. For example, the value of excellent products and services that can advance the development of whole persons or sustain the natural environment cannot be fully captured by exchange prices and other economic measurements in an organization's financial statements. A more balanced public interest perspective engages students to reflect more deeply on how externalities and their future work as accounting professionals will affect the welfare of persons and institutions.

\section{Subprime Mortgage Lending: The Case of New Century Financial Corporation}

Colby et al. $(2011,53)$ asserted that liberal education's traditional purpose is "to enable students to make sense of the world and their place in it, [to prepare] them to use knowledge and 
skills as [a] means toward responsible engagement with the life of their times." The global financial crisis that began in 2008 provides a rich example of the larger cultural, moral, and institutional contexts in which accounting theory and practice are embedded. Whereas Arnold $(2009,804)$ proposed a research agenda aimed at understanding accounting's role in the financial crisis, we propose an education agenda aimed at translating and communicating this understanding in public interest terms that are accessible to accounting students.

Knapp's (2010) New Century Financial (NCF) Corporation case addresses some aspects of the role of accounting and auditing in the global financial crisis. The case also includes the traditional types of questions raised in accounting ethics cases, such as those involving the auditor's professional roles and responsibilities, internal control testing and reporting requirements, and proper procedures to support reliable accounting estimates such as loan loss reserves. These traditional issues and concerns comprise an essential part of an accounting education, but they clearly do not exhaust the important public interest issues. For example, while the global financial crisis of 2008-2009 may be partly attributable to management fraud, audit failures, and overconfidence in the ability of the capital markets and financial engineering techniques to manage risk (Arnold 2009; McSweeney 2009; Power 2009), it also was arguably embedded in a larger cultural and moral crisis in which business leaders who pursued their own private interests failed to align the good of their corporations with the common good. Below we provide some background on the NCF executive misdeeds and then examine the broader public interest issues in more detail.

The evidence indicates that executives at NCF knowingly misrepresented their financial condition and the adequacy of their internal controls. For example, NCF's $200510-\mathrm{K}$ filed with the U.S. Securities and Exchange Commission made the following false assertions:

We originate and purchase loans on the basis of the borrower's ability to repay the mortgage loan, the borrower's historical pattern of debt repayment and the amount of equity in the borrower's property...We believe...we have developed a comprehensive and sophisticated process of credit evaluation and risk-based pricing that allows us to effectively manage the potentially higher risks associated with this segment of the mortgage industry.

In subsequent financial reporting periods, NCF executives continued to reassure investors that their company's system of internal controls was strong and sophisticated. But in fact, the company's information technology and data-processing systems were not state of the art. For example, key loan origination and monitoring processes were manual and so poorly designed that it was easy to manipulate the loan underwriting and appraisal systems. NCF systems and personnel did not adequately track its highly material loan repurchase obligations and did not have a formal policy for calculating loan loss reserve requirements. NCF consequently failed to establish an adequate reserve for loan losses. Even while the highly compensated NCF's executives saw their company's financial and operating condition deteriorate significantly in 2005 and 2006, they continued to overstate the company's assets and understate its liabilities and expenses. On September 8, 2006, one day after internal discussions identified much worse than expected loan repurchase requests, NCF issued a press release stating that it had "strict underwriting guidelines" and "skilled risk management," and that its early-payment loan defaults in August were only "modest." On April 2, 2007, NCF filed for bankruptcy.

Altogether, the above summary indicates that NCF executives violated financial reporting regulations and failed to prudently manage their company's loan loss risks. The lack of accountability and moral responsibility at so many levels by accounting and other business 
persons not only at NCF but also at a wide spectrum of other financial institutions suggest that the subprime crisis was fundamentally a cultural failure and not simply an economic, political, or technical accounting failure. This is not to underestimate the complexity of the causes that drove the business failures at NCF, Countrywide Financial, Fannie Mae, Freddie Mac, AIG, Washington Mutual, Lehman Brothers, and others. It does suggest, however, that our legal and regulatory institutions were not solely to blame, and that our ability to prevent similar systemic failures in the future will require more than introducing and enforcing new regulations, better financial incentives, or more sophisticated enterprise risk management practices (cf. Power 2009, 849).

Below we illustrate how the NCF case can be used to probe some of the broader public interest issues. The overlap between our questions and the questions raised in traditional accounting and auditing cases is an advantage because it illustrates how accounting educators can incrementally introduce more public interest and liberal education themes in their existing accounting courses without having to substantially revise their existing course materials. In the following examples, brief discussion points appear in italics.

1. Why do you suppose Bob Cole, Ed Gotschall, and Brad Morrice founded New Century Financial Corporation? Explain how their business motives could be framed in terms of (a) promoting the public interest and (b) harming the public interest. Refer to the Mission and Identity components of the Three-Fold Model of Organizational Life (Specht and Broholm 2009) and define what the public interest means to you in the subprime lending context. These questions provide an opportunity for students to discuss competing views about subprime lending's role in advancing or harming the public interest. For example, making loans available to less creditworthy borrowers made homeownership available to those groups, at least in the short run, but it also harmed a significant percentage of those same groups who eventually lost their homes in foreclosure. In addition, the eventual demise of NCF and other large financial institutions harmed investors, creditors, taxpayers, and citizens across the globe. The activities described in the NCF case and other publicly available evidence indicate that the NCF founders were primarily motivated to enrich themselves and placed inadequate weight on the Mission component. Individual character and motivation also matter, and could be partly addressed through hiring and training practices. In this particular NCF case, however, the executives in question founded the company and in essence hired themselves. In these circumstances, effective governance and internal control could constrain the executives' opportunistic behavior, but the question may arise as to whether the executives would voluntarily design controls to effectively constrain their actions. This provides an opportunity to discuss the professional responsibilities of external auditors to evaluate a client's internal controls and thereby identify weaknesses in organizational design. A public interest emphasis also suggests that more emphasis on employee development (Identity) could have given employees better training and tools not only to develop and practice better loan origination and review activities, but also to better serve customers, creditors, and investors in the long run (Mission). Greater organizational emphasis on the Mission and Identity dimensions also can foster a deeper appreciation of the vocational dimensions of one's work, such that professional pride and caring for others could motivate some individuals to forgo some private economic gain to better advance the organization's mission. While existing corporate practices and professional codes do not require this degree of attention to Mission and Identity, a widespread failure to pay sufficient attention to those dimensions had demonstrably adverse consequences for the welfare of diverse societal interests. 
2. Refer to the Committee of Sponsoring Organizations of the Treadway Commission (COSO 2004) Enterprise Risk Management (ERM) Framework. How might a more effective internal environment and other elements of risk management have enabled New Century Financial to better serve the public interest? This question engages students to reflect on the relation between enterprise risk management and the public interest. Business executives who are concerned to promote the social purpose of their business (other than solely through the pursuit of profit maximization) and who understand what that means will identify mission-relevant public interest objectives (e.g., sustainable home ownership; prudent long-term investment and funding mechanisms) and will be willing to expend more resources to identify and manage the risks that could prevent their organization from achieving those objectives. The limitations of the ERM framework also could be discussed. For example, the ERM framework was designed to handle risk management at the enterprise level, but it poorly addresses risk management among multiple highly interconnected firms and may foster complacency and overconfidence (cf. Power 2009, 850). Awareness of the social meaning and potential public interest impact of professional accounting work should include awareness of the limitations of accounting practices and technologies.

3. Evaluate the following statement: "A strong commitment to effective risk management would have required the NCF executives to be willing to forgo profit and frame the meaning of their work and the purpose of their business differently, in public interest terms." In your answer, refer to concepts from the course readings. Again, this question engages students to reflect on the tradeoffs among Stewardship and Mission. Better loan origination and review practices would have reduced profit (at least in the short run), not only by raising expenses to create and maintain a better information and internal control system for establishing more realistic loan loss reserves, but also by forgoing revenue from questionable loan originations. As noted earlier, if the executives had been more committed to vocational concepts of work they likely would have placed more value on such public interest objectives as the professional development of their employees and the ability of their company to genuinely serve its customers and investors. Such public interest objectives would have guided the organization's leaders to exchange some short-term profit for a more sustainable business enterprise. In addition, as noted under Question 1, effective corporate governance and internal control along with their evaluation by external auditors could have constrained the opportunistic and socially destructive activities of NCF executives. Even if executives are opportunistic and disinclined to design and maintain a reasonably effective system of internal control, public accountants have a duty to publicly disclose the control weaknesses and, if the weaknesses are highly material, possibly resign from the audit engagement. Public accountants who exercise diligence and due professional care under already existing professional codes and regulations can play a meaningful role in aligning a client's activities with the public interest.

4. Aside from legal requirements, what obligation or responsibility, if any, do you believe managers and accountants have to protect the interests of homeowner borrowers? Explain the basis for your answer. While the discussion here might include an acknowledgement that some homeowners were at least partly responsible for their own foreclosure difficulties, the primary objective is to address the roles and responsibilities of accounting and business professionals. Students may be encouraged to draw from their own traditions and experiences to articulate their personal commitments and views about professional responsibilities. This often-neglected personal dimension of an accounting education is 
important because it provides a basis for advancing the public interest that cannot be found solely in professional codes and regulations. Among other readings, we have used excerpts from Chapter 19 of the Book of Leviticus from the Hebrew scriptures to engage students to reflect on their professional responsibilities. In particular, Leviticus 19:14, which enjoins against putting a stumbling block before the blind, is concerned not only with the material welfare of the morally blind or financially naïve prospective homeowner, but also the moral and spiritual development of business executives. The general point is that a person's moral values, commitments, and imagination may be shaped by his or her inherited traditions. When we offer examples from specific spiritual traditions, we do so with the intent of eliciting a meaningful dialogue and we invite students to bring examples from their own traditions.

We offer the above NCF case as an example of what could be done to incrementally modify existing accounting and auditing cases. Even just small changes may be sufficient to engage students to reflect more deeply on the broader public interest dimensions of their future work as accounting professionals. Other accounting educators might prefer to use other cases to explore the intersection of accounting and the public interest. For example, those who teach tax accounting might develop a case based in part on Hamill's (2002) biblical critique of the social-justice implications of the state of Alabama's regressive tax structure, or they might apply this paper's analysis of institutions and the social purpose of business to Rostain's (2006) description of the aggressive tax shelter practices once promoted by KPMG and other large public accounting firms. Relevant background readings from the liberal arts and humanities could then be chosen to fit the specific cases.

\section{Relating Public Interest Themes to Students' Life Experiences}

Our approach to integrating liberal and accounting education aims to develop students' awareness of the relations among their personal and future professional lives, the purpose of business, and the common good. Toward meeting these objectives, students can be asked to demonstrate through oral discussions and written essays their own understanding of how concepts from the humanities and social sciences relate to their social, cultural, and economic life experiences (cf. McPhail 2001, 489-490). This section describes an integrative essay assignment that asks students to interrogate their own personal histories and faith experiences in order to better understand their vocational choices and aspirations. Accounting education programs that do not have space in their courses for this type of assignment might instead encourage students to voluntarily undertake a similar reflective exercise through their participation in a student accounting club or other extracurricular activities.

Appendix A describes the three parts of the final integrative essay. Part 1 of this assignment asks students to consider their chosen profession in terms of Hardy's (1990) categories of interests, gifts, talents, and societal needs, and to reflect on how their personal life stories (family, education, religion, work, etc.) influenced their decision to pursue a particular line of work. Accounting educators could explore similar themes through other readings on vocation and professional ethics (e.g., Martin 2000). Part 2 asks students to discuss how their undergraduate major field relates to the mission or purpose of the kind of organization where they plan to work. Part 3 asks students to anticipate some structural barriers that could prevent them and their profession from achieving the common good, and to anticipate conflicts that might arise between their personal commitments and the public interest. For an example of the latter, marketing or accounting students might be asked to consider what they would do if a client sells products or 
services that the student would find objectionable. Our principal objective here is to raise students' awareness about the difficult and sometimes irresolvable tensions and conflicts they may encounter in their future professional work. Although most students have not yet had significant work experience in the field of accounting, some of our course readings (e.g., Hardy 1990, Chap. 4; Salkin 1994; Williams 2010) provide anecdotes to help students engage more concretely with these issues.

Excerpts from the students' final integrative essays provide some evidence on how they used the course concepts to articulate how they began to see the world and their own lives differently, made sense of their lives retrospectively, and articulated their personal beliefs and selfunderstandings in a publicly accessible manner. For example, the following excerpt from an accounting major's final essay illustrates integration between vocational perspectives on work and the student's self-understanding of what led him to choose the field of accounting:

The most dominant factor in choosing my major was finding something that utilized my abilities well. As Hardy puts it, I wanted to find "the gifts God has given me, and exercise those gifts for the sake of others." These gifts are my understanding of numbers and how they relate to each other, as well as the ease of learning accounting principles that others do not grasp so easily. Hardy also tells us that God provides several tools to help us discern our potential job calling, mainly, concern and lively interest. I feel that accounting is a proper calling, since I tend to be more 'concerned' with people's financial wellbeing, and I have a 'lively interest' in working with numbers.

Like many of our students, the above student used conceptual brevity to describe his selfunderstanding of how he would like to apply his intellectual, analytic, and quantitative skills to enhance other people's lives. His reference to Hardy (one of our course readings) is appropriate because the reading and our class discussion of it more fully articulated the relation between the public interest and the development and application of one's talents, abilities, and interests.

Each student is encouraged to selectively focus on the readings they believe best articulate their position. While the assignment requires students to engage with the course readings, we include some optional readings on our course website and students also may draw from other readings. In addition, while the essay assignment asks students to discuss specific course readings and concepts, no student is required to agree with all of the course concepts. For example, students are not required to express a deep personal commitment to their future work as a vocation. The following excerpt from a graduating finance and economics double major engaged with the relevant course concepts but also demonstrated that he thought of his past and future work primarily as a job and a career rather than a vocation:

I see myself as a proletariat because I am bound to the process of work. My education is a job to me. It is a requirement and a means to an end. It is necessary to get a bachelor's degree to achieve a higher salary and more challenging career in the future ... I chose part-time jobs, activities, even volunteering on the basis of whether it will improve my resume and make me marketable for a lucrative career in the future.

We do not conclude that the above student's candidly expressed instrumental focus necessarily means that he failed to grasp the course concepts. Perhaps student loans and an impending graduation without having yet received a viable job offer amplified this student's instrumental concerns. Our objective is not to indoctrinate students or convince them to adopt a certain set of beliefs, but rather to give them some resources to more deeply explore the relation 
between their personal commitments and their future professional lives, and through that exploration ultimately better serve both themselves and the public interest.

The longer-term impact of our course on students' thinking about their personal and professional lives may not always be immediately apparent. The following example indicates that our course had a transformative effect on a student's thinking during the semester and especially after he graduated. This student had graduated from high school as Valedictorian and graduated from college with a 3.97 GPA and Summa Cum Laude. In the opening pages of his final integrative essay he described himself as a proletarian and how he learned from his parents "to love work and focus on it to the exclusion of leisure." In his early teen years he began to attend weekly Mass and "sought for the first time to place worship at the core" of his life. But a few years later he was disillusioned by "an arrogant priest who would later be arrested for embezzlement" and "work had once again consumed" his life. He continued to reflect on his personal and professional commitments, and wrote that "the insights gained through [the course] have allowed me to consider my future goals not only in light of my talents and the economic appeals but also in terms of a vocation"; that he was concerned "to retain a work-life balance"; and that he recognized that "working in accounting may be a challenging long-term career path." He accepted a position as a tax associate at an international public accounting firm, and was told initially that the group to which he was assigned would not require 60-65 hour workweeks during busy season. But, soon after he joined the firm, he was reassigned to a group with a much heavier workload.

After graduation and a few months of full-time tax accounting work, the above student wrote the following comments in an email addressed to one of the authors:

I wanted to send you an update regarding my first few months on the job and what I've been noticing. . . I recently sat down to read again what I had composed for the final paper [in our class] and spent some time reflecting on it in light of my "real-life" experience these past few months. To start with, one of the first things that I noticed on the job was the lack of work-life balance with many of the people working in this office ... The people here have very little time to spend with family or engaging in authentic leisure ... A few have talked about how they actually enjoyed having to work $10+$ hours a day for over a 10-day period (including Saturdays and Sundays). I have come to see such a fixation on one end as unhealthy and detrimental to ourselves. By seeking to engage with my own tradition and having it become part of my daily life, I feel much more relaxed and in a better balanced (for lack of a better word) position ... I have always been a strong supporter of the idiom that organizations exist solely to maximize the wealth of their owners ... [Now] I can much more easily see how companies can, and should, contribute to social goods and provide for their employees ... I can see how Milton Friedman was both right and wrong in his thinking ... I would have liked to see more courses that integrated disciplines - those would have been extremely valuable.

Six months later, one of the authors sent a brief email to this student to inquire about how things were going. Here are some excerpts from the student's reply:

It is very good to hear from you ... A few days before Thanksgiving, I was let go by the firm ... It is quite ironic that before our class, I clearly was someone acclimated and content with the proletarian lifestyle. Yet, that class was the start of my changing views to work and life ... I was told that because I was not working until midnight or later on my own free will, I was not helping out the team enough. This is despite the fact that I was already working around 10 hours a day ... They said that by leaving to eat dinner at my 
home, I was a bad example for the firm. And all of this is in spite of my work that some partners and directors told me was of extremely high quality and completed far under budget ... I'm still working on some of my side projects and business endeavors as I try to find a full-time job ... I'm also seeking a company that values a work-life balance. I'm very glad for our class. It truly is a life changing class.

In conclusion, as the above examples illustrate, the integration of liberal and business education can give students analytical and intellectual resources to better understand their personal commitments and their world. But, it cannot guarantee that they will immediately secure and maintain personal and professional fulfillment through their employment in a particular firm or line of work.

\section{DISCUSSION}

This paper offers a vision of an accounting education in the public interest that integrates liberal and business education. We define the public interest based on the concept of the common good, where the good of individual persons and the good of the community both matter. Accordingly, our approach focuses on the development of holistic persons and holistic institutions. The whole person focus engages students to reflect on the relation between their personal commitments and future professional work, to develop awareness of themselves as not just economic but also moral and spiritual beings, and to see their future accounting work as a vocation that contributes to the welfare of society. The institutional focus exposes students to alternative perspectives on the purpose of business, ranging from an almost exclusive focus on shareholder wealth maximization to a broader concern for the private and mutual interests of all stakeholders. We also introduce a three-dimensional view of organizations that encompasses not only the acquisition and growth of resources (Stewardship), but also the development of people who work in the organization (Identity) and the provision of goods and services that can have a positive impact on external parties (Mission). While accounting students tend to be most familiar with the stewardship dimension, a healthy organization requires sufficient attention to all three dimensions.

Our approach to integrate liberal and business education aims to complement rather than replace existing code- and rule-based approaches to teaching accounting ethics. While research indicates that the ability to identify a situation as an ethical dilemma is necessary in order to respond to the situation in an ethically appropriate manner (Massey et al. 2009, 487; see also, Armstrong et al. 2003, 4), it clearly is not sufficient. Indeed, in many well-documented cases the accounting and tax professionals in question knew they were violating applicable tax regulations, financial reporting rules, or other professional codes. Those cases suggest that we cannot reduce all accounting ethics to legal compliance or universal philosophical maxims. Rather, we may also need to examine the cultural, moral, and spiritual factors that can mobilize a person to act in the public interest even in the midst of contrary pressures.

In light of the structural barriers to integrating liberal and accounting education, we describe how the integration needs to be consciously planned, organized, and delivered to engage students to see linkages among their personal and professional commitments, work, leisure, and the common good. We also acknowledge that our university setting is different than that of many accounting educators. Consequently, what works best will depend on institutional fit, and what works for us may need to be adapted and scaled. We accordingly illustrated how some general public interest objectives may be applied in traditional accounting courses. Our examples have 
several features that make our approach accessible to accounting educators across a variety of college and university settings.

First, we apply our liberal learning ideas to traditional accounting cases that accounting educators may already find familiar. Even incremental adaptations can beneficially introduce more public interest themes in traditional accounting cases. Similarly, whereas most introductory accounting texts tend to emphasize the shareholder primacy perspective to the exclusion of other perspectives on the social purpose of business (e.g., Ferguson et al. 2005), small changes in those books might be sufficient to raise students' awareness of alternative ways to frame the public interest issues. We emphasize that accounting educators would not need to develop entirely new cases or textbooks from scratch, or engage in wholesale redesign of their existing courses. Second, in developing our theme of accounting education in the public interest, we draw from recent critiques of accounting and business practices (e.g., Arnold 2009; Hopwood 2009; Power 2009; Williams 2010) and relate their conclusions to concepts from the liberal arts and humanities. Third, some elements of our pedagogy build on ideas that have been expressed in the extant literature on professional ethics (e.g., Martin 2000; Williams 1981), liberal education in business (e.g., Colby et al. 2011), and critical perspectives on accounting education (e.g., McPhail 2001; Shapiro 2009). By locating our approach within these multiple literatures, we establish the generality of our approach and identify other academic resources that accounting educators can use to develop their own approach.

A key part of our pedagogy involves juxtaposing background readings from the humanities with accounting and business examples. The rationale is that by drawing explicitly from theological, philosophical, and other material outside of accounting, we give students a substantive basis to formulate, argue, and defend their normative views and conclusions about the public interest implications of accounting practices and institutions. We believe that students will be able to engage more deeply in these important critical ideas if they are exposed to interdisciplinary literature on such topics as the social purpose of business, the concept of vocation and its relation to the public interest, the multiple origins of an entity's resources, and the multiple dimensions of human flourishing. These normative commitments motivate our examples from philosophy and theology. Other accounting educators may prefer to draw from other literature in the humanities. For example, Lister (2010) described how he integrates the study of English literature with accounting, and a course on Professional Responsibility and Leadership at New York University includes Cicero's On Duties as a background reading to engage students with questions about how to reconcile their personal commitments and interest in career advancement with a commitment to ethical integrity and pursuit of the common good (see Colby et al. 2011, 58). From whatever literatures an integrative course or program of courses might draw its normative inspiration, the liberal learning objectives should be to engage students to reflect more deeply on the relation between their personal and professional commitments, and to become more aware of the irresolvable tensions that may arise between their private interests and the public interest.

In conclusion, this paper explores how accounting educators can use concepts from the liberal arts and humanities to engage students to explore the public interest implications of accounting practices, and to reflect on how their future professional work can relate to their personal lives. We still have much to learn about accounting's roles in financial scandals, in the increasingly global nature of financial crises, and in enabling positive individual and social outcomes. Although we can never completely resolve the tensions and conflicts that arise between personal commitments and the public interest, we can give our students more intellectual and analytical resources to reflect on their future professional work in broad social and personal terms. 


\section{REFERENCES}

Accounting Education Change Commission (AECC). 1990. Objectives of Education for Accountants. Position Statement No. One. Sarasota FL: American Accounting Association.

Alford, H. J., and M. J. Naughton. 2001. Managing as if Faith Mattered. Notre Dame, IN: University of Notre Dame Press.

Armstrong, M. B., J. E. Ketz, and D. Owsen. 2003. Ethics education in accounting, moving toward ethical motivation and ethical behavior. Journal of Accounting Education 21: 1-16.

Arnold, P. J. 2009. Global financial crisis: The challenge to accounting research. Accounting, Organizations and Society 34 (6-7): 803-809.

Austin, J. E., H. B. Leonard, and J. W. Quinn. 2004. Timberland, Commerce and Justice. Cambridge, MA: Harvard Business Publishing.

Baker, C. R. 2005. What is the meaning of "the public interest"? Examining the ideology of the American public accounting profession. Accounting, Auditing and Accountability Journal 18 (5): 690-703.

Blanthorne, C., S. E. Kovar, and D. G. Fisher. 2007. Accounting educators' opinions about ethics in the curriculum: An extensive view. Issues in Accounting Education 22 (3): 355-390.

Boyer, E. L. 1990. Scholarship Reconsidered, Priorities of the Professoriate. San Francisco, CA: Jossey-Bass, Inc.

Boyer, E. L. 1992. Scholarship reconsidered, priorities of the professoriate. Issues in Accounting Education 7: 87-91.

Brooks, D. 2012. The Jeremy Lin problem. The New York Times (February 16): A27.

Carter, S. 1999. Civility, Manners, Morals, and the Etiquette of Democracy. New York, NY: HarperCollins.

Colby, A., T. Ehrlich, W. M. Sullivan, and J. R. Dolle. 2011. Rethinking Undergraduate Business Education: Liberal Learning for the Profession. San Francisco, CA: Jossey-Bass.

Committee of Sponsoring Organizations of the Treadway Commission (COSO). 2004. Enterprise Risk Management Framework. New York, NY: AICPA.

Cooper, D. 1994. Expanding the horizons of research on accounting education. Contemporary Accounting Research 11 (Supplement): 163-167.

Cuganesan, S., R. Gibson, and R. Petty. 1997. Exploring accounting education's enabling possibilities: An analysis of a management accounting text. Accounting, Auditing and Accountability Journal 10 (3): 432-453.

Douglass, B. 1980. The common good and the public interest. Political Theory 8 (1): 103-117.

Ferguson, J., D. Collison, D. Power, and L. Stevenson. 2005. What are recommended accounting textbooks teaching students about corporate stakeholders? The British Accounting Review 37: 23-46.

Fogarty, T. J. 2010. Revitalizing accounting education, a highly applied liberal arts approach. Accounting Education 19 (4): 403-419.

Friedman, M. 1970. The social responsibility of business is to increase its profits. The New York Times Magazine (September 13): 87-91.

Gallhofer, S., and A. Chew. 2000. Introduction: Accounting and indigenous peoples. Accounting, Auditing and Accountability Journal 13 (3): 256-267.

Gallhofer, S., K. Gibson, J. Haslam, P. McNicholas, and B. Takiari. 2000. Developing environmental accounting: Insights from indigenous cultures. Accounting, Auditing and Accountability Journal 13 (3): 381-409.

Gilligan, C. 1982. In a Different Voice. Cambridge, MA: Harvard University Press.

Hamill, S. P. 2002. An argument for tax reform based on Judeo-Christian ethics. Alabama Law Review 54 (Fall): 1111.

Hardy, L. 1990. The Fabric of This World: Inquiries into Calling, Career Choice, and the Design of Human Work. Grand Rapids, Ml: Wm. B. Eerdmans Publishing Company.

Heschel, A. J. 1951. The Sabbath. New York, NY: Farrar, Straus and Giroux.

Hopwood, A. G. 2009. The economic crisis and accounting: Implications for the research community. Accounting, Organizations and Society 34 (6-7): 797-802.

Hurtt, R. K., and C. W. Thomas. 2008. Implementing a required ethics class for students in accounting: The Texas experience. Issues in Accounting Education 23 (1): 31-51.

ljiri, Y. 1975. Theory of Accounting Measurement. Studies in Accounting Research \#10. Sarasota, FL: American Accounting Association.

International Federation of Accountants. 2010. A Public Interest Framework for the Accountancy Profession. IFAC Policy Position Paper \#4 (November). New York, NY: International Federation of Accountants.

International Federation of Accountants. 2011. A Definition of the Public Interest. IFAC Policy Position Paper \#5 (September). New York, NY: International Federation of Accountants. 
Jacobs, K., and S. P. Walker. 2004. Accounting and accountability in the lona Community. Accounting, Auditing and Accountability Journal 17 (3): 361-381.

John Paul II. 1990. Ex Corde Ecclesiae (Encyclical on Catholic Universities). Rome, Italy: The Vatican.

Knapp, M. C. 2010. New Century Financial Corporation. In Contemporary Auditing: Real Issues and Cases, 7th edition, edited by M. C. Knapp, 135-151. Mason, OH: Cengage Learning.

Langenderfer, H. Q. 1987. Accounting education's history-A 100-year search for identity. Journal of Accountancy 163 (5): 302-331.

Lewis, C. S. 2001. The Great Divorce. New York, NY: HarperCollins.

Lewis, C. W. 2006. In pursuit of the public interest. Public Administration Review 66 (5): 694-701.

Lister, R. J. 2010. A role for the compulsory study of literature in accounting education. Accounting Education 19 (4): 329-343.

Maclntyre, A. 1984. After Virtue. Notre Dame, IN: University of Notre Dame.

MacIntyre, A. 2001. Catholic universities, dangers, hopes, choices. In Higher Learning and Catholic Traditions, edited by R. E. Sullivan, 1-21. Notre Dame, IN: University of Notre Dame Press.

Marsden, G. M. 1997. The Outrageous Idea of Christian Scholarship. New York, NY: Oxford University Press.

Martin, M. W. 2000. Meaningful Work: Rethinking Professional Ethics. New York, NY: Oxford University Press.

Massey, D. W., and J. Van Hise. 2009. Walking the walk: Integrating lessons from multiple perspectives in the development of an accounting ethics course. Issues in Accounting Education 24 (4): 481-510.

McPhail, K. 1999. The threat of ethical accountants: An application of Foucault's concept of ethics to accounting education and some thoughts on ethically educating for the other. Critical Perspectives on Accounting 10 (6): 833-866.

McPhail, K. 2001. The dialectic of accounting education, from role identity to ego identity. Critical Perspectives on Accounting 12 (4): 471-499.

McSweeney, B. 2009. The roles of financial asset market failure denial and the economic crisis: Reflections on accounting and financial theories and practices. Accounting, Organizations and Society 34 (6-7): 835-848.

Nash, L. 1994. Believers in Business. Nashville, TN: Thomas Nelson Publishers.

New Century Financial Corporation. 2005. Form 10-K Annual Report Pursuant to Section 13 or 15(d) of the Securities Exchange Act of 1934, for the Fiscal Year Ended December 31, 2004 (Filing Date March 16, 2005). United States Securities and Exchange Commission, File Number 000-22633. Irvine, CA: New Century Financial Corporation.

Newman, J. H. 1982. The Idea of a University. Notre Dame, IN: University of Notre Dame Press.

Parker, L. D. 2012. Qualitative management accounting research: Assessing deliverables and relevance. Critical Perspectives on Accounting 23 (1): 54-70.

Pieper, J. 1948. Leisure, the Basis of Culture. South Bend, IN: St. Augustine's Press.

Power, M. 2009. The risk management of nothing. Accounting, Organizations and Society 34: 849-855.

Roberts, J. 1991. The possibilities of accountability. Accounting, Organizations and Society 16 (4): 355-368.

Roberts, J., and R. Scapens. 1985. Accounting systems and systems of accountability. Accounting, Organizations and Society 10 (4): 443-456.

Rorty, R. 1989. Contingency, Irony, and Solidarity. New York, NY: Cambridge University Press.

Rostain, T. 2006. Travails in tax: KPMG and the tax shelter controversy. In Legal Ethics, Law Stories, edited by Rhode, D. L., and D. J. Luban, 89-118. New York, NY: Foundation Press.

Salkin, J. K. 1994. Being God's Partner: How to Find the Hidden Link Between Spirituality and Your Work. Woodstock, VT: Jewish Lights Publishing.

Shapiro, B. 2009. A comparative analysis of theological and critical perspectives on emancipatory praxis through accounting. Critical Perspectives on Accounting 20: 944-955.

Shearer, T. 2002. Ethics and accountability: From the for-itself to the for-the-other. Accounting, Organizations and Society 27 (6): 541-573.

Smith, T. W. 2008. Catholic social thought and modern liberal democracy. Logos 11 (1): 15-47.

Soloveitchik, J. 1965. The Lonely Man of Faith. New York, NY: Three Leaves Press.

Specht, D., and D. Broholm. 2009. Three-Fold Model of Organizational Life. Shelburne Falls, MA: Seeing Things Whole.

Stark, J. S., and M. A. Lowther. 1988. Strengthening the Ties That Bind: Report of the Professional Preparation Network, University of Michigan. Ann Arbor, MI: University of Michigan Board of Regents.

Sundem, G. L. 1999. The Accounting Education Change Commission: Its History and Impact. Accounting Education Series, Volume 15. Sarasota, FL: Accounting Education Change Commission and American Accounting Association. 
Swanson, D. L. 2005. Business ethics education at bay, Addressing a crisis of legitimacy. Issues in Accounting Education 20 (3): 247-253.

Union of American Hebrew Congregations. 2001. Sacred Partnership: Readings and Exercises for Self Study on the Relationship Between the Professional and Volunteer Leadership in Reform Congregations. Available at: http:// urj.org//cong/board//?syspage=document\&item_id=14858

Williams, B. 1981. Moral Luck. Cambridge, U.K.: Cambridge University Press.

Williams, D. Z. 1991. The challenge of change in accounting education. Issues in Accounting Education 6: 126-133. Williams, P. F. 2010. The focus of professional ethics: Ethical professionals or ethical profession? Research on Professional Responsibilities and Ethics in Accounting 14: 15-35.

Wilson, J. Q. 1993. The Moral Sense. New York, NY: Simon and Schuster Inc.

Yuengert, A. Forthcoming. Roman catholic economics. In Oxford Handbook of Christianity and Economics, edited by P. Oslington. Oxford, U.K.: Oxford University Press.

Zeff, S. A. 1989. Does accounting belong in the university curriculum? Issues in Accounting Education 4 (1): $203-210$.

\section{APPENDIX A}

\section{Instructions for Final Integrative Essay}

1. Your Past and Your Work/Leisure: The objective of this part of the essay is to encourage you to reflect on your past and integrate course material in order to see patterns that influence your life choices. In light of your life stories (family, education, religion, work, etc.), what main influences and motives have shaped your future work decisions? When answering this question, please discuss Hardy's (1990) categories of interests, gifts, talents, and needs. What are the things that you find most interesting? What kinds of gifts do you have? What are you good at? What do you see as the critical needs of our society? Discuss theological or philosophical ideas from Pieper (1948), Heschel (1951), Soloveitchik (1965), or Salkin (1994) in your discussion of leisure and vocation. Consider the following kinds of experiences you have had in different institutions:

a. Family Experiences: What are the central values of your family as it relates to work and leisure? What experiences within your family embody these values?

b. Faith/Religious Experience: What experiences of faith and religion have formed you? What insights do you have about Pieper's notion of leisure as it relates to its contemplative and feast dimension? What kind of leisure do you think will foster your chosen kind of work? What do Adam the First and Adam the Second have to contribute to this discussion?

c. Educational Experiences: What are the driving principles of your education, especially as it relates to your work?

d. Work Experiences: In terms of your experiences of work thus far, would you describe your future work as a job, a career, or a vocation?

2. Your Future and Your Institution: Discuss the purpose of the institution (business, church, non-profit) in which you plan to work and how it relates to your undergraduate major field. In light of your understanding of the purpose of this institution, what principles do you think can guide you toward being a "highly principled" leader? How do these principles relate or not relate to the Catholic social principles? How does your undergraduate major field promote or not promote these principles? What impact do you see your field having on organizations, society, and the development of individual persons? 
3. Challenges: Discuss some social, political, and other institutional obstacles that could make it difficult for your major field to promote the common good. Discuss theological and/ or philosophical ideas from Lewis (2001), Pieper (1948), Heschel (1951), Soloveitchik (1965), Alford and Naughton (2001), or other course readings that you believe could effectively mitigate the obstacles you identified. 